\title{
Mapping Capital in Mexico This Month (1955-1971)
}

\begin{abstract}
This chapter, based on original archival work on Mexico/This Month, responds to Susannah Glusker's invitation to undertake 'an analysis of [its] contribution ... in promoting Mexico' (Glusker 1998: 15), with a particular focus on cartography and capital. The chapter, through a close reading of its trademark Explorers' Maps series, and drawing on pertinent work on cartography from a range of disciplines, suggests that Mexico This Month visually and discursively mapped a fantasy of capital that is related to, yet destabilized by, a second, more problematic fantasy of conquest. The chapter also enquires into the impact of capital on the magazine's external periodical code, that is, the relation between the conditions of its state funding and its endurance as a material artifact over its lifetime.
\end{abstract}

Keywords Art - Commerce - Cartography - Capital · Conquest • Tourism 
Maps offer arguments and propositions; they define, recreate, shape and mediate. Invariably, they also fail to reach their objectives. (Brotton 2012: 16)

In a 1959 audit of the travel magazine, Mexico This Month, a prospective buyer criticized the quality of its copy, claiming that some of it was 'so badly written that it was impossible to edit'. S/he also censured the inflated wages of its staff artists, indicating that if $s /$ he were to take over the magazine's management, 'I would insist upon firing [them] ... and buy such material on an assignment per piece basis'. The North American was exercised by the cost and style of the magazine's artwork, which s/he considered 'pretentious and arty to the extent of being obscure and effete ... of a school which I would not, in all justification and knowledge of this business, accept.' In the auditor's view, a magazine for public consumption 'must be on a least common denominator level, communicating instantly the intent of the writer or artist'. The existing artwork, $\mathrm{s} /$ he advised, contradicted the commercial aims of the magazine in which 'Good photographic cover would be infinitely better, have more punch and Sell [sic] than the obscure approach of [the artist] Vlady who seems dearly in love with his own work'. There was, aside from a practical recommendation to purchase an addressograph, an equally blistering account of the magazine's operations and its 'shameful' mailing and circulation systems: the incumbent editor's laissez faire handling of those affairs was decried as 'a fatal violation of all concepts of publishing' (Brenner 1959). Such unvarnished remarks, without reference to the object of criticism, might lead one to expect little from the periodical in question. In fact, Mexico This Month was far from the calamity diagnosed in that withering report. Its seventeen-year run is something of a record in a market 'characterized by a heavy mortality rate', in which other contemporary illustrated magazines in Mexico were vulnerable because of the increasing encroachment of their advertising revenues by television. As Richard D. Woods has observed, in the lifetime of Mexico This Month some seven magazines of a similar character, which had an average shelf life of five years, folded (Woods 1990: 209). Moreover, the periodical was well received in the US press as 'fascinating and reasonable' and compared favorably with The New Yorker and others of 'our better magazines' (Brenner 1967). Yet the auditor's report is striking as well as strident in its expression of the apparently trenchant dissension between art/culture and commerce, which is one of this book's central concerns. That is, their comments raise issues of a magazine's 'acceptable' content (digesting its defining admixture of visual and 
written material) and imply a correlation between category or type of magazine and symbolic capital-the popular vs the more high brow publication-in which enduring dichotomy culture is pitted against capital. In what follows, I suggest that such an opposition is not quite as irreducible as that auditor suggests.

This chapter focuses on Mexico This Month, a title that was established in Mexico at the height of the country's so-called economic miracle. Based on original archival work on this magazine, which has received no scholarly attention to date, it responds to Susannah Glusker's invitation to undertake 'an analysis of the contribution of Mexico This Month in promoting Mexico' (Glusker 1998: 15). First, the chapter elucidates the context of magazine's genesis and gives an account of how Mexico This Month operated as a vehicle for boosting tourism and the economy at a critical period of Mexico's modernity. The chapter's second section then attends to the function of what would become in its early years the travel magazine's trademark centrefold maps, which were drawn by the same artist at the receiving end of the auditor's invective cited above. Maps are ubiquitous in the practice and experience of tourism, of course; they convey information about places, provide ideas for journeys, and are also employed by tourists as a means to learn about the histories and environments of different routes and sites. ${ }^{1}$ Yet, as Stephen P. Hanna and Vincent J. Del Casino Jr. point out, these material representations of space, 'produced and interpreted in changing social contexts,' are 'complexly and intertextually interrelated with the spaces and identities [they] strive to represent' (2003: xi). Through a close reading of the magazine's Explorers' Maps series, and drawing on pertinent work on cartography from a range of disciplines, I suggest that Mexico This Month visually and discursively mapped a fantasy of capital that is related to, yet potentially destabilized by, a second, more complex fantasy of conquest. The third section of the chapter enquires into the impact of capital on the external periodical code of Mexico This Month, in particular, the relation of the conditions of the magazine's funding to its existence as a material artefact over its lifetime. The 'mapping' I invoke in the chapter's title, therefore, notwithstanding the term's 'proliferating and metaphorical promiscuity' (Craib 2004: 3), refers to both its literal and symbolic meanings, to the magazine's cartographic content as well as to my methods. Taking my cue from scholars in geography, history, visual culture, and cultural studies who are interested less in 'maps as finished artifacts than ... in mapping as a creative activity' (Corner 1999: 217), the following analysis sheds light on the complex ways in which this magazine was invested in the aesthetics, geopolitics, and economics of tourism during Mexico's post-war/Cold-War 
years. In essence, it considers the ways in which the Explorers' Maps series of Mexico This Month not only represented the country at that time, but imaginatively produced it, for as Jerry Brotton reminds us, 'mapmakers do not just reproduce the world, they construct it' (2012: 7).

Mexico This Month first appeared in 1955, in the midst of the decades of rapid economic growth known as the 'Mexican miracle' when, in an indication of the country's newly found economic and political strength, investment in and expansion of the tourism sector increased exponentially. This was a period in which the country was steered towards rampant capitalist development by Miguel Alemán, 'arguably the most important president in twentieth-century Mexican history ... [and] a real genius of modern Mexican political life' (Sherman 2010: 537, 538). Alemán's government, dependent on a unique political coalition formed of rich industrialists and a rising urban middle class, accelerated industrialization, invested heavily in infrastructure projects, suppressed trade union activity, and openly courted foreign capital (so much so that 'rich Americans and Mexicans united to a degree not unlike that seen during the Porfiriato'). One consequence was indeed an economic 'miracle', in which Mexico averaged close to $6 \%$ annual gross domestic product (GDP) growth into the 1960s, 'one of the highest sustained rates recorded in the world' and output from manufacturing, a sector that benefitted especially from the investment of US capital, rose by a factor of ten (Sherman 2010: 544). Another consequence was that, as rural Mexico failed to benefit from the urban development then underway and modernization did nothing to address inequality, Alemanismo effectively undid many of the radical reforms put in place by his predecessor Lázaro Cárdenas: as John Sherman puts it, under Alemán, the "former "enemies" of the Revolution ... were now its beneficiaries, and by the time he left office, the "institutionalized revolution" was one only in name' (2010: 539). Thus, the postwar period emblematizes one of the central paradoxes of Mexico's twentieth-century history, which is 'extraordinary in that a revolutionary movement, which experimented with collectivist and even socialist modes of production, led to such a deeply inequitable capitalist regime' (Gillingham and Smith 2014: 2).

Alemán (who was known as 'the father of Mexican tourism') had deeply and personally invested in the development of tourism, from which he amassed a vast personal fortune. On the one hand, as Alex 
Saragoza has noted, Alemán made concerted efforts to modernize Mexican tourism: "Tourists eager to experience "Mexican culture" found an infrastructure to provide it, readymade availability and the exotically different' (2001: 108). On the other hand, Alemán bought and profited from land and property in Baja California and Veracruz as well as prime real estate in Acapulco, which, after the end of his term of presidential office and under his subsequent tenure of the position of Minister of Tourism, became transformed into a world-class resort. ${ }^{2}$ Advances in infrastructure facilitated growth in the sector: a number of superhighways were opened in Mexico during the 1950s, including a direct four-lane road south from Mexico City to Acapulco, the transnational Christopher Columbus Pan-American highway from El Paso to the Guatemalan border, and other routes from Nogales to Guadalajara and from Mexico City to Puebla, Cuernavaca, and other cities in the Bajío. By 1957, Mexico had fifteen thousand miles of paved roads, 'a testimony to both the government's commitment to road building and the technology of new paving equipment imported from the United States,' (Sherman 2010: 547) just one indication of the benefit Mexico accrued from US business interests during that period. At the same time there was substantial development and state investment in the aviation industry, to which Acapulco's success owed considerable debt. New routes opened up the skies to a greater number of airlines, while long-standing carrier American Airlines bestowed planes with 'Mexican' names such as 'the Aztec' and 'the Toltec' in order to compete in a more crowded market (Boardman 2001: 95). Further, a new airport opened to the southeast of Acapulco, Guadalajara's airfield was expanded and some \$5 million of investment was ploughed into Mexico City's Benito Juarez airport in 1953, which also marked the year of Mexico's first National Tourism Congress (Sherman 2010: 548).

During this Golden Age of prosperity, a self-styled group of businessmen called the Comité norteamericano pro-México launched Mexico This Month, under the editorship of Anita Brenner. This group of North American executives, bankers and long-term Mexico City residents formed in June 1954, in the wake of that year's devaluation of the peso, with the avowed purpose to 'fomentar las buenas relaciones entre México y los EEUU de Norteamérica, mediante actividades culturales, cívicas y publicitarias' [encourage good relations between Mexico and the United States of North America, through cultural, civic and advertising activities] (Brenner, n.d.). Their congregation, 'set up as a working mechanism to cooperate with the then newly organized National Tourist 
Commission, headed by Secretary of the Interior, Angel Carbajal', had official encouragement and endorsement from the Mexican state, the then Finance Minister Gilberto Loyo and President Adolfo Ruiz Cortínez $(1: 1,1955,6)$. Their endeavours, under the chairmanship of John McIntyre (of General Motors) and the banker William Richardson, were clearly motivated as much by commercial as putatively 'philanthropic' or diplomatic interests, as General Motors and the National City Bank of New York were regular advertisers in the magazine. The magazine was conceived as a means of improving social and business relations between Mexico and the United States by promoting travel, investment, and retirement in Mexico. Brenner articulated her agenda and participation in cultural terms: as a traveller 'who incited travel' (Monsivais 2010: xvii) in journalism and guidebooks throughout her career, she insisted on the need for such a vehicle to project a more progressive image of Mexico to its northern neighbours. The magazine became a tool for counteracting what Brenner described as a prevailing 'desconfianza hacia Mexico' [distrust of Mexico] and a 'prensa hostil' [hostile press] in the north, where Mexico and Latin America had long been viewed as morally decrepit, politically unstable, and economically and racially backward. ${ }^{3}$ Mexico This Month was thus conceived as a response to a geopolitical as well as an economic crisis. It aimed to intervene in and boost a fitful tourist market in the post-war decades, and, in doing so, promote commercial interests north and south of the border. In this respect it was very much part of what Ricardo Salvatore (1998), drawing on Stephen Greenblatt, terms the representational machines of informal empire, in which business and knowledge are interconnected. Mexico This Month announced this purpose in its manifesto, 'Operation Amigos', in the inaugural issue:

[W]e believe that one of the best ways to create a better understanding between two peoples is through travel. Our main effort is, therefore, being directed to the promotion of increased travel to and from Mexico ... [and] in putting Mexico into English we will be doing our own piece of the big job of rapprochement towards which America is moving ... [for] Today the idea of a thriving and contented neighbor is good business and good politics. $(1: 1,1955,5)$

Encouraging tourism and investment was conceived as a means of soft or informal diplomacy, a way of 'hac[iendo] ambiente, para ir 
desvaneciendo confusiones y agresiones' (Brenner 1964) [creating an atmosphere, in order to dispel misunderstandings or aggressions] or, as Brenner put it elsewhere, 'friendliness, understanding and helpfulness as a good international recipe' (MTM, 2:4, 1956, 7). In an industry in which 'even the slightest hint of danger can destroy a destination' (Clancy 2001: 127), and in the context of a country sensitive to criticism abroad, as we saw in the Introduction, the potential impact of the magazine's efforts to counter adverse images of Mexico, to 'bring dollars down, to help ease away unnecessary or unreal fears' (Brenner 1955), cannot be underestimated.

But how did the magazine do this exactly? From its inception, Mexico This Month was conceived as a bi-national project, as 'la voz de Mexico en inglés' [the voice of Mexico in English] (Brenner, n.d.). It brought together unknown and established Mexican and North American writers and artists to promote the country's history, geography and culture, some of the better known of which were Frank Brandenburg, Leonora Carrington, Matias Goeritz, Juan Rulfo, and Leopoldo Zea. Brenner's insistence on their 'non-professional' status as writers and artists, rather than journalists and illustrators ('we knew nothing about business, production, advertising or distribution' she claims, 2:4, 1956, 7) was strategic. On one level, as Faye Hammill and Michelle Smith suggest, invoking 'originality and artistry rather than technique and craftsmanship, indicate $[\mathrm{s}]$ an aspiration towards high culture which is typical of the middlebrow [magazine]' (2015: 87). On another level, however, in the case of Mexico This Month, it underscores the avowed function of the magazine's collective 'unbusiness-like objectives' $(14: 4,1958,7)$ as cultural and diplomatic (rather than wholly commercial) work, while potentially forestalling the kind of wounding public criticism Brenner encountered earlier in her career, in the Holiday debacle discussed in the Introduction. In its early years, the magazine's international roster of contributors was a badge of honour ('on our staff are represented six nationalities, about double the number of languages ... about the only other place a staff like this could be found in one enterprise might be Paris'). This speaks not only to the large influx of foreigners visiting and residing in Mexico since the 1920s and 1930s, but also to the magazine's tactical cosmopolitanism; that is, 'the dynamics of good-neighbour ideas at work ... a sort of pilot project of the nations in the hopeful building of a saner world' $(3: 4,1957,7)$. A letter from the US ambassador Fulton Freeman thanking Brenner for her efforts at 'correcting some misleading impressions 
about Mexico and its relations with the US' published in the magazine endorsed and legitimized these endeavours: 'Real success [in promoting understanding between peoples],' Freeman wrote, 'depends upon the kind of initiative and sense of responsibility shown by private citizens like yourself and Mexico This Month' (X:11, 1965, 8).

In essence, in its focus on sites of touristic interest, aspects of Mexico's cultural heritage, indigenous peoples and traditions, as well as its social and political life, Mexico This Month was a blend of the kind of coverage offered by its bilingual predecessor Mexican Folkways and its counterpart Mexican Life, with the more popular tone and look of magazines on both sides of the border such as Life and Siempre! Those, as part of their 'modern' agenda, attempted to engage readers by placing a strong emphasis on visuality and by covering the lives of celebrities. Thus, Mexico This Month ran special issues on different regions of the country, highlighting places of touristic interest. It combined features on destinations such as the capital, the Colonial Cities and Acapulco; on museums, archaeological sites and fiestas, together with seasonal advice for travellers on what to pack and what to wear, a series on 'Basic Mexican', as well as coverage of, say, 'The Kennedy Sensation' on JFK's 1962 visit to the country. Like Mexican Folkways, Mexico This Month also covered and promoted the work of Mexican artists, inter alia Diego Rivera, José Clemente Orozco, Leonora Carrington and Francisco Goitia, a profile of whom in the magazine's second issue was illustrated with photographs by Edward Weston. Writers were also featured: Mexico This Month commemorated the award of the 1958 Villarutia prize to Octavio Paz for his El arco y la lira, for example, and covered the furore provoked by the publication by the Fondo de cultura económica of Oscar Lewis's The Children of Sanchez, a work of an 'outsider' speaking of the squalor that afflicted large parts of Mexico. ${ }^{5}$ Like Toor with Mexican Folkways, Brenner envisioned a pedagogical and archival function to Mexico This Month: in a reformulated manifesto-cum-advertisement in the magazine's January 1968 issue, she maintained that it is regularly used as reference by key people in politics, publishing, business and education throughout the US' and 'is the only English language publication on Mexico used regularly and widely for reference and study in US schools' (XIII:1, 1968, 1).

Encouragement of tourism and investment took variegated forms in Mexico This Month. More overtly, these included a regular column called 'National Panorama', which reported to readers on the stock market 
situation; on the country's banking laws; on aspects of government policy (recounting a presidential address, for example, or a piece-written by Loyo-on foreign investment in Mexico). The overwhelming emphasis in such items was on the country's political stability, its economic security, and the benefits of development and industrialization. Richardson writes in the magazine's debut issue of 'a combination of conditions [that] makes Mexico one of the best risks available to capital in Latin America' $(1: 1,1955,4)$, for instance; while the regular News and Comment section documented 'the increased confidence and security of the Mexican economy' $(1: 4,1955)$, some issues later 'placing Mexico definitely in the industrial age and as a modern nation' (2:4, 1956, 8). Throughout its lifetime, the magazine published features by leading figures in the tourism industry, such as Gustavo Ortiz Hernán, director of the Mexican government Tourist Bureau, and it published special numbers in May 1958 on 'Tourism' and in November 1970 on 'Convention Mexico', the latter in collaboration with the National Tourism Council, the Mexico City Convention Center and the state Tourism Department. The inclusion of a pull-out 'Happy shoppers' map of where to spend money in Mexico City effectively' (2:12, December 1956), as well as a special series on retirement (entitled 'Search for Eden') and regular articles on the purchase of property were other iterations of that same agenda. ${ }^{6}$ In 'The Real Estate Story', for example, readers were urged to

Go out and buy yourself a house ... you'll have a wonderful time with it ... be sure not to feel the curbs of convention ... The Mexican way is strictly freedom to style your own. $(4: 10,1958,23)$

Meanwhile, in a piece called 'Taxco suitcase', 'wise visitors' were advised 'to leave at least half their suitcase vacant for silver, its innumerable varieties of jewelry, flatware and so on' $(2: 6,1956,5)$. Moreover, the magazine ran abundant advertising from major companies such as General Electric, Ford, Mobiloil, Air France, Aerolíneas Mexicanas, Monsanto, Bacardi, Chanel, and Nescafé. Some of this copy was tactically 'indigenized', a marketing manoeuvre then in vogue, as we saw earlier with American Airlines; for example, General Motors affiliated the ancient engineering feats of the Aztecs to the complex technology of its Buick model, depicting in a hand-drawn illustration the pyramids at Teotihuacán in an advertisement in the December 1956 issue. 
In essence, through all of these means, Mexico was imagined as a large potential market, a magnet for consumers and investors alike. It is notable that during a decade in which the country was developing a reputation as a haven for alterity and adventure for bohemian visitors from the North, the longer-stay visitors of Mexico This Month's readership-an older, affluent demographic of professionals and businessmen-were of particular interest to the Mexican state. For while the 'miracle' had been successful in augmenting their number, the type of US tourist attracted to Mexico had also by the mid 1950s begun to cause concern, as Michael Clancy has observed: 'Short stays contributed to relatively low spending per visit and the reputation of border areas as centres of vice and smuggling intensified' (2001: 45).

More subtle devices in the magazine to foster a sense of hemispheric fraternity and intimacy, and to convey this shift in Mexico's reputation from that of the unruly to the good neighbour, included a regular page of readers' correspondence. This was a forum that functioned much like an information bureau in print form and which eventually became known as 'The Question Desk'. It addressed queries from 'Monthers' (as the magazine fondly addressed its readers) regarding accommodation, routes, or shipping charges and facilitated the purchase of particular consumer items: notwithstanding the kind of postal inefficiencies discussed in Chapter 1, this was eventually formalized into a paid-for service. ${ }^{7}$ Also published was readers' correspondence on issues germane to the periodical. 'I found the magazine real chatty-like a nice intimate conversation-or a letter from home' (6:4, April 1960, 6), observed one; another urged the editor, 'por favor, don't ever make Mexico This Month too slick, too proofread. Love it the way it is' $(10: 9,1965,28)$; while another, a high school principal from New York, complained about the content not being appropriate for his eight-year-old pupils, 'you will recall that we told you all about tequila and things' (8:7, October 1962). Yet readers also responded to and enquired about the particularities of the country's politics and culture: 'Can you please tell us how Mexico operates as a democracy with apparently only one political party?’ (6:4, April 1960, 6).

In an editorial entitled 'Person to Person', Brenner addressed readers directly in every issue, focusing on an item of topical interest, or interpreting an aspect of Mexico's culture or current events. At times the editorial provided a space in which she defended Mexico's efforts in international relations, especially in light of disadvantageous coverage north of the border with/in the United States. In this respect, and 
in the broader context of the Cold War, when international tourism became codified symbolically and politically as a democratic activity, the magazine operated explicitly as a form of informal international diplomacy. This is a testament to the power of mainstream consumer publications to 'produce publics and counterpublics' and 'advance particular causes' (Hammill et al. 2015: 12). In an August 1955 issue, for example, Brenner decried the 'horrendous picture of this country on the skids' painted by [North] American journalism, lamenting that the only beneficiary of such enmity between neighbours could be 'the Moscow mill' $(1: 3,1955,7)$. Elsewhere, in relation to that same climate of heightened suspicion and distrust, Brenner was forced to clarify and distinguish the magazine's use of the word communal from 'that other word' (1:7, $1955,7)$. Consistently, through this channel, Brenner drew her readers' attention to Mexico's geopolitical strength and its potential for leadership within Latin America more generally, insisting that 'what's good for Mexico, is likely to be good for the US' $(6: 4,1960,7)$ : 'she alone possesses the material basis for continental leadership ... no Latin country is better equipped to interpret Latin America to the US' $(5: 4,1959,23)$. More controversially for her US readers, from 1960 onwards Brenner used the 'Person to Person' editorial to defend Mexico's stance on Cuba, which rested on a policy of non-intervention (though opposed to Soviet militarization, Mexico was supportive of Castro's revolutionary social and economic reforms):

It is the impression of the Cubans that the American government is trying to bully them, and this is also to a considerable extent the impression in Mexico and other Latin American countries. Having been indubitably bullied themselves, Mexicans often hair-trigger to any merest hint of a suggestion of this, so, though they may be looking askance at Castro as you are, they figure it's up to the Cubans who they want at the head of their government. $(6: 8,1960,7$, original emphasis)

This editorial was followed by a feature by Daniel James in the October 1960 edition called 'Mexico is Mexico' in which he assured that, while unprepared to condemn Castro, Mexico remained opposed to communism-'Mexico is not going to imitate Cuba' (8)-and that the maintenance of the friendliest possible relations with the US was a cornerstone of Mexican policy. Notwithstanding, over subsequent months and years the letters pages of Mexico This Month, attested to the polarised 
responses to that position and of the magazine's alignment with it: on the one hand, indignation at the periodical's 'ultra-liberal' attitude $(7: 1$, 1961,28 ) and cancelled subscriptions ('I intend to have nothing to do with Mexico or things Mexican in the future', 6:10, 1960, 6) and, on the other, unqualified support, urging the reprinting of the magazine's editorial material on the matter in all major US newspapers. Brenner vindicated the stance in her coverage of President López Mateos's 1963 European tour and his policies on nuclear disarmament, claiming that: 'Mexico's positions of being neither "neutral" nor even "uncommitted" exactly, but just plain not belligerent, however cold the war' afforded it 'a torch-bearing role' in peace work $(9: 2,1963,10)$. At all times, and whatever the subject, Brenner sought to reconcile her writing in that and other sections of the magazine with its congenial politics: 'The style,' she avowed, 'has been kept easy and casual on the theory that a tone as of an acquaintance or friend talking is better than noise and bombast' (Brenner 1964). ${ }^{8}$

\section{II}

One of the most striking aspects of Mexico This Month's visual repertoire in its early years was a series of hand-drawn, centrefold maps of Mexico, its capital and other popular tourist destinations such as Veracruz and Acapulco. Created by its staff artist, Vladimir Machados (the nom de plume of a Russian émigré artist then resident in the capital and son of the exiled revolutionary novelist Victor Serge), these colourful 'Explorers' Maps' distilled various facets of the prevailing tourist discourse about Mexico as an embodiment of modernity and antiquity. The series was published at a time when there were significant advances made in the production of tourism maps. Although the coupling of maps and tourism dates back to the late nineteenth century, when large oil companies spotted the promotional potential for marketing their products and printed road maps to be given away for free at petrol stations, the close association between the two became consolidated particularly during the interwar period. ${ }^{9}$ Technological developments and diminishing production costs meant that maps had become cheaper to produce and tourism maps, 'creat[ing] an idealized image of their chosen location so that it would appeal more powerfully to their customer', became more affordable and more widely distributed than ever before. Indeed, it was precisely in the 1950s when such maps also started to become more elaborate, 
embellished with colourful images and notes about interesting places to stop en route. As Tom Harper has observed: 'Maps in guidebooks and postcards illustrated commercial air travel routes and holiday destinations, using colour, advertisement, and a highly pictorial style to enhance their appeal' (2016: 169). Accordingly, the Explorers' Maps series of Mexico This Month - which included an array of plans of cities, states, highways, ports, and fishing zones-in addition to promoting the country's security and stability, emphasized Mexico's accessibility and navigability. To some degree, the maps served like conventional tourism maps or those in a travel or guidebook: to provide a chart of a particular destination, say, or a bird's-eye view of the nation's geography, as well as to orient and enable readers to traverse routes to, in, and between different locations. Yet, rather than mere visual adjuncts or simple guides to the routes travelled, the series' maps constitute complex representations with their own narrative and iconographic qualities and histories. Indeed, the story of the Explorers' Map series of Mexico This Month that unfolds here is one about maps as intertextual objects which, as Hanna and del Casino argue in their work on the 'map space', 'are materially interconnected to other spaces and texts, both past and present, and are thus rich sites for the critical interrogation of tourism practices and spaces' (Hanna and del Casino 2003: xxvi). In contrast to the 'pseudo-objectivity' of plain 'scientific' maps, the Mexico This Month centrefolds were highly stylized and embellished pictorial maps that often belied the avowed (but now increasingly disputed) clarity and neutrality of cartographic technology. Further, as will become clear in what follows, the Explorers' Maps visualized and affirmed Mexico's diversity and history in complex, even contradictory ways.

Maps have long been bound up in the articulation of power and authority, the geographical information they relay typically the preserve of ruling elites: as such, throughout history, as Jerry Brotton observes, 'for shamans, savants, rulers and religious leaders, maps ... [have] conferred arcane, magical authority on their makers and owners' (2012: $3)$. This has a particular resonance in the context under scrutiny here, where, since Independence, as an emerging nation Mexico has been subject to repeated journeys of mapping, 'the means by which to identify and assume control over resources, to reconfigure property relations, and to generate knowledge of the territory' as well as to document customs and character. Indeed, mapping became such an obsession of agrarian bureaucrats and state officials in modern Mexico, that, Raymond 
Craib avows, 'one could plausibly argue that the state and cartography are reciprocally constitutive' (Craib 2004: 9). Yet that enterprise to create a spatial imaginary of Mexico (a 'state fixation', as Craib puts it) was not uncomplicated but a 'much more ambivalent and dialectical process than one of some state juggernaut imposing its visions upon an either quiescent or intransigent countryside' (Craib 2004: 13). The readings of the Explorers' Maps of Mexico This Month that follow attest to that very complexity. However, if framing is a territorializing gesture, as Denis Cosgrove (1999) reminds us, the magazine centrefolds' repeated emphasis on visualizing Mexico as a discrete political unit, in addition to establishing a discursive intertextuality within and beyond the series, speaks to an issue of 'branding' - as much of the periodical as of the nation itself-and insinuates a nationalist rhetoric of sorts. ${ }^{10}$ That is, the visual recurrence of and insistence on Mexico's human, cultural, and political geography over the four years of the Explorers' Map series' existence (the whole sequence of images comprising an atlas in serialised form) resonates with efforts at a national level during that period to assert the country's identity as a modern Republic, to enable readers within and outside the country to recognize and identify (with) Mexico and to provide a sense of belonging to a nation. For, as Ricardo Padrón observes, 'the form of collective self-fashioning that we know as the nation-state ... is inseparable from a clear image of a territory that inspires our affection, demands our loyalty, calls us home' (2004: 9).

The iconic power of the nation's contours was not lost on advertisers in the pages of Mexico This Month. Kodak, in one of its advertisements in the magazine, used an image of a reel of camera film shaped in the recognizable form of Mexico's geography, in order to assure readers that 'It's the same word in Mexico!'. Il Kodak's appropriation of Mexico's semblance to a cornucopia is pertinent: it recalls another key function of maps, to 'support capitalism both practically and ideologically' (Harper 2016: 141), not only as commodities in themselves, but in their very production as a profit-making enterprise. ${ }^{12}$ The commercial importance of maps dates back to the colonial period under the Portuguese and Spanish empires, which established their value as route-finding tools and tried to standardize their production by means of institutions like the Casa de la Contratación (House of Trade) in Seville. ${ }^{13}$ Yet, the then reduced publishing industry in the Iberian peninsula compared to that of northern Europe lead to a significant paradox: that is, as Brotton describes, that 'the maps they produced were invariably hand-drawn in 
a futile attempt to limit their circulation' at a time when 'a new world was being defined by new ways of making money' (Brotton 2012: 263, 264). Mexico This Month provided symbolic and concrete means for its readers of satisfying that same acquisitive impulse in the modern period. For instance, the recurrence of an imperial figure in the Explorers' Maps series-whether invoked in narrative or in pictorial form (as was also the case in the images accompanying the 'Search for Eden' series on retirement, which commonly included the figure of a Spanish conquistador bearing golf clubs) - speaks to commercial activity and infers that modern Mexico was still ripe for exploration, exploitation, and extraction. In the twentieth-century age of mechanical reproduction, a further (historical) contradiction emerges in relation to these images of the Explorers' Maps, which were distributed separately from their original form in the series precisely because of their hand-drawn, 'Colonial' style. Following their widespread appeal and success, the Explorers' Maps were marketed and sold individually as artisanal, 'folkloric' products. This pull-out, spinoff function speaks to the map's potential as commodity, as mentioned above, and also to the broader operations of modern capitalism in which the magazine was invested and which it sought to foster. Although in this instance the maps were sold in portable foldaway leaflets, in some cases it is debatable how much practical use they would have been for orientation purposes (a point to which I return below): indeed, it is praise for their aesthetic or souvenir value as artefacts that is documented in the readers' and editorial pages of the magazine. Nevertheless, in both centrefold and separate leaflet forms, the maps were bound up in a long tradition of mapping for commercial purposes as well as in the magazine's early attempts at diversification, name recognition, and loyalty. If the hand-drawn was invoked in the colonial period as a means to curtail, it was now deployed as a technology from which to expand circulation.

Insofar as the Explorers' Maps of Mexico This Month were about identity, collectability, and ersatz utility, they spoke an equivocal visual language, fusing the geographical with the thematic, the narrative with the iconographic, devices modern with pre-modern. That fusion of seemingly dialectical characteristics is inherent in the design and construction of maps themselves: as 'graphic representations that facilitate a spatial understanding of things, concepts, conditions, processes, or events in the human world' (Harley and Woodward 1992: xvi), all maps are always already hybrid, variegated texts in form and composition. Throughout history they have appeared in myriad material forms, including cloth, 
tablet, drawing, and print, and while they exist as material objects maps are graphic documents that are at once written and visual: as Brotton remarks, 'you cannot understand a map without writing, but a map without a visual element is simply a collection of place names' (2012: 5). Likewise, insofar as all maps are to some degree shaped by scientific principles or data, 'there has always been art in cartography' (Harmon 2009: 9). That is, not only are artistic skills and techniques required in order to make 'an ultimately imaginative representation of an unknowable object (the world)' and produce an abstraction of it to 'a series of geometrical lines and shapes' but they can also be applied creatively to enhance a map's effect. Indeed, it was in the last decades of the twentieth century, following the decolonization of many developing countries and during the greater economic and political uncertainties of the 1960s and 1970s, that there was an 'exponential increase in artists [themselves] working with maps' (Harmon 2009: 9). Gayle Clemans usefully sums up the differences in cartographic practice: if geographers 'submit to a tacit agreement to obey certain mapping conventions, to speak in a malleable but standardized visual language. Artists are free to disobey these rules' (Harmon 2009: 10).

The Explorers' Maps series was no exception in this respect, its creator(s) proving to be incisive and creative in their insertion into this aesthetic and political legacy. For example, the magazine archly claims its map of La Lagunilla in Mexico City (a traditional market held over several blocks of the city centre, where 'quite literally anything can be bought') to be 'so far as we know, the first effort ever made at a truly scientific survey of this fascinating territory' (1:9, 1955, 13) (Fig. 4.1).

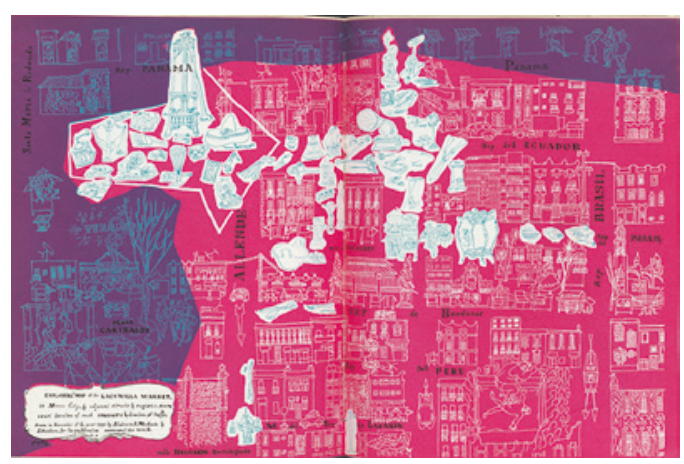

Fig. 4.1 Explorer's map of La Lagunilla market, Mexico This Month, 1:9, 1955 
Continuing on this theme, the map's legend declares that it shows 'the exact location of each speciality and direction of traffic', with each subset of merchandise sold at the market indicated by blue and white pictorial figures located at particular junctures on a grid formation of streets. Major thoroughfares are identified by name (República de Honduras, República del Perú, and so on), as are some buildings by their commercial use. The faux cartographic precision of this discernibly handdrawn plan is both enhanced and offset by its decorative colours: the market's domain is defined by an area in an arresting shade of deep pink, the borders beyond which are in a majestic purple. This vivid drawing, 'done in Colonial style, printed in three [sic] colours on fine paper, ready for framing or guiding explorers' $(1: 9,1955,28)$ became the prototype for the magazine's series of portable maps for purchase.

In the Explorers' Maps of the Paseo de la Reforma and Chapultepec, which portray one of Mexico City's main avenues and parks respectively, key buildings, sites, and monuments - such as Bellas Artes, the Torre Latinoamericana, and the Angel of Independence-are highlighted on the itineraries through vast distortions in perspective as well as through their depictions in the kind of intense colours that emblazoned the Lagunilla map, in these cases red and white against a black filler and green background in the former, blue, grey, and white in the latter. As a result, in terms of the absence of any information pertaining to scale or projection as well as their embellishments in proportion and colour, both maps have the look of caricature, in which respect they are likely to have had touristic appeal as the collectable items they became after publication.

The Reforma map (Fig. 4.2), which appeared in the September 1958 issue, and was co-produced by Machados and C. van Millingen, conveys a strong sense of the capital city's architectural hybridity, as it plots a visual itinerary of one of Mexico City's most important arteries and a history of downtown establishments and sites of interest. These are documented in two separate but consecutive legends in the upper left-hand and lower right-hand corners of the map. The Paseo de la Reforma was originally opened in the 1860s under Emperor Maximilian as a way to link the Castillo de Chapultepec in the west of the city with the central main square, the Zócalo. As such, it is an avenue of considerable historical as well as geographical importance in Mexico City, consisting of a wide central thoroughfare bisecting once elegant neighbourhoods populated by the Porfirian gentry and flanked on either side by a double row of trees, private mansions, and apartment buildings that began to appear 


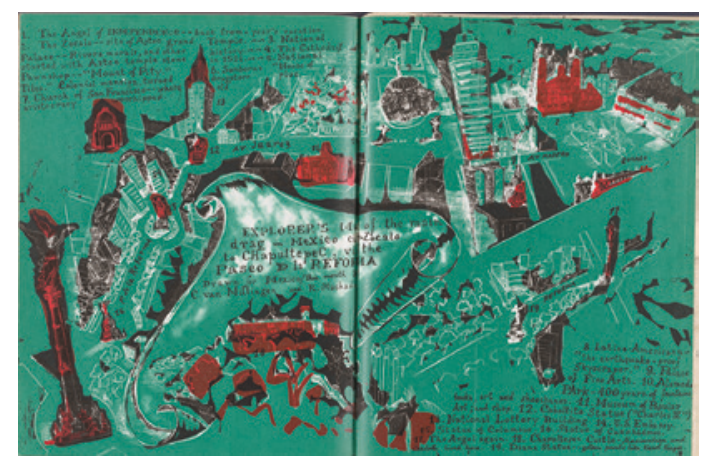

Fig. 4.2 Explorer's map of the main drag in Mexico city, via the Paseo de la Reforma, Mexico This Month, 4:9, 1958

in the 1890s. ${ }^{14}$ The 'spine of the ideal city', as Mauricio Tenorio Trillo puts it, the Paseo de la Reforma was developed during the Porfiriato as a chronological reconstruction of the nation's history, one 'that aimed to reconcile the ideas and events of a real past with the ideals and needs of an inexperienced ruling class that was trying to guide a new nation' (Johns 1997: 24). The form that took along this boulevard was the erection of a series of monuments of national heroes including Charles IV, Columbus, and Cuauhtémoc, which, together with the Angel of Independence are positioned in an arrangement that 'all but ignored Mexico's past as a colony while praising the European world that Spain had introduced it to' and 'celebrated Mexico's roots in Aztec society, but uncertainly’ (Johns 1997: 24), as Michael Johns remarks. ${ }^{15}$

On the Mexico This Month map, at either end of the route, there is the Zócalo ('site of Aztec grand temple' the legend tells us) and Chapultepec Castle ('Maximilian and Carlota lived there') while along it are depicted Sanborns ('Colonial mansion turned drugstore plus'), the Torre Latinoamericana ('the earthquake-proof skyscraper') and the Alameda Park (' 400 years of fountains, books, art and shoeshines'). The Angel of Independence, in the map's lower left-hand corner and the Zócalo, in the top right-hand corner, frame the route spatially and aesthetically: as with the Cathedral, Chapultepec Castle, the Museum of Popular Art, and the statues to Charles IV ('el Caballito'), Columbus, and Cuauhtémoc along the Reforma, the red and black shading of white line drawings highlight and animate those buildings and statues in expressive fashion. The map's intense colours are evocatively cast in the 
hues of the Mexican national flag, predominant in the maps' green background, white line drawings, and red shading. The dominance in the lower left-hand corner of the map of the Angel monument, 'conceived as the universal symbol of Mexico's modernism and sovereignty', underscores that chromatic allusion to nationalism, for as Tenorio writes, 'El Angel is the nation, apparently accepted by all, though revered in different ways' $(2012: 22,24)$. Moreover, the map's urban landscape is dominated by the height of its soaring skyscrapers, its towering Torre, and other prominent monuments that surge from ground level (as well as from the constrictions of the 'normative' urban grid) at random, oblique angles and jostle for the readers' eyes and attention. For all that riotous spectacle, however, this is a city plan haunted by vacancy; the unfilled outlines of unpopulated buildings, anonymous apartment blocks, and avenues empty of pedestrian and vehicular traffic. As such, the dynamic but unoccupied Paseo de la Reforma map speaks of the city's aspirations and reach: it functions both as an assertion of the country's historical achievements and contemporary ambitions and as an invitation, one that promises to the city's visitors availability, potentiality, and wonder.

The Map of Chapultepec Woods, which appeared in the magazine in January 1956, works with a more orthodox sense of proportion, save, once again, for the depiction of the Angel monument that looms large in the map's top right-hand corner (Fig. 4.3). In contrast to the emptied built environment of the Reforma image, this cartographic close-up of a 'forest park with a castle on a hill' ('the most romantic spot in fabled and storied Mexico City', 2:1, 1956, 13), now home to the official

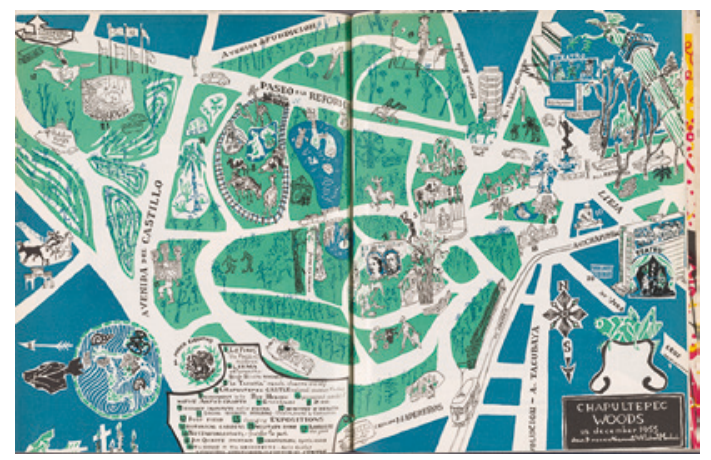

Fig. 4.3 Map of Chapultepec Woods, Mexico This Month, 2:1, 1956 
presidential residence, is teeming with pictorial figures, bustling activity and movement, of people, animals, and various modes of transit (car, bus, tram, and horse). The bucolic quality of the park, its zoo and planting (its thousands of distinctive abuehuete trees) - '[with] the air of a place in which Druids are still very much at home and where anything can happen' $(2: 1,1956,13)$-is emphasized by the soft green colouring of the map's black, green, and white palette and contrasts with the urban pleasures and entertainments (restaurant, cinema, and theatres) situated at its gates. The whole map is about sports and leisure pursuits available at this site-whether football, horse-riding, driving, tennis, bullfighting or boating, alongside eating and attending the theatre or cinema-multiple pastimes for a retreat for Mexico City dwellers and visitors alike. Like all good tourism maps, the Chapultepec plan provides navigable pathways and routes, shaded white, throughout this animated and verdant site. The singular qualities of this space as respite from Mexico City's quotidian geography and temporality are enhanced by the lack of detail provided of the spaces surrounding the park, except for a collection of named avenues such as Reforma and Avenida del Castillo, which are devoid of physical detail and whose dark turquoise fillers give the impression of their submergence under water, a visual reminder perhaps of the springs lying below Chapultepec that once supplied the city's drinking water (Brenner 1932: 108).

The quality of excess evinced in both maps of the Reforma and Chapultepec-which is at stake in many others of the Explorers' Maps series, in different ways-is significant in these cases also at a phenomenological level. As Rob Shields avers, tourism maps have an especially close relationship to bodily experience: they provide sources of guidance for those unfamiliar with the place 'to fit into a ritualized path ... eliminating the necessity of asking directions from locals' (2003: 16). Indeed, as a form, the map conventionally rests on notions of containment and accessibility, on encouraging the traversal of space with ease. The proportional and aesthetic distortions in the Paseo de la Reforma map, however, emphasize density, verticality, and depth, and necessarily move the tourist gaze away from ground level to attend to the circuitous and vertiginous negotiation of the route/site and the historical character of urban space. Shields' observations on the function of maps as props are particularly resonant here in respect of both the Reforma and Chapultepec maps: 'representing an entire city or a day's walk in a map, [tourism maps] distance the tourist, nose in map, from the everyday interaction of residents, 'he writes. The Explorers' Maps' coverage, 
design, and their characteristic colourings also direct the experiential and embodied quality of the visit, 'making the tourist present in a specific, tinted ... staging of place' (Shields 2003: 16).

If the time-honoured accessibility promised by cartography is undermined by the subjectivity of the Explorers' Maps (which also calls into question their utility as material objects), the expression and promotion of Mexico's modernity in Mexico This Month, to which I referred in the previous section, is in turn destabilized by the map series' particular aesthetic. In terms of composition, the maps repeatedly deploy cartouches, alongside other cartographic signs and symbols that evoke the iconographic language of colonial, and pre-modern, map making. In this regard, the imperial figure featured in the Search for Eden series mentioned above recalls the tour describers of early maps, which indicated the military and commercial operations that made possible the fabrication of a geographical plan at all (its sporting guise as a golfer in Mexico This Month alluding to the imperialist underpinnings of modern leisure travel) (de Certeau 1984: 121) (Fig. 4.4).

This figure also appears in 'The Trail of Cortés: A Map for Intrepid Explorers' (3:8, August, 1957), which invites readers to re-trace the original colonial incursion from Veracruz to Tenochtitlán, through various key battle sites. The image's asymmetry in scale between the large pictorial figure of an armoured Spanish conquistador and other symbols which dominate the route and the minute, indecipherable urban plans of Veracruz and Tenochtitlán that frame the beginning and end of the trail is telling. Although the legend names eleven stages along the way, including Jalapa, Tlaxcala, and Cholula, otherwise the urban plans are unreadable. 'The Trail of Cortés' map is not so much about how to negotiate

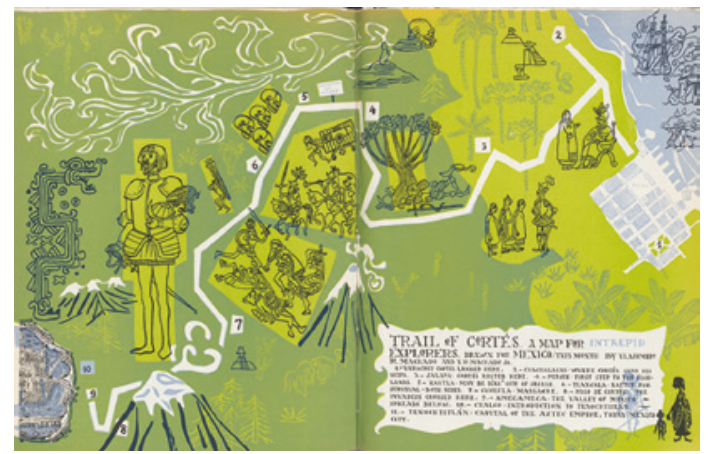

Fig. 4.4 Trail of Cortés, a map for intrepid explorers, Mexico This Month, 3:8, 1957 
that route, therefore, than about the history that has shaped it. The map's symbols and figures-including a pre-Columbian temple, a serpent, a collection of skulls, and other pictorial figures depicting, at different junctures, Cortez and La Malinche, Spanish conquistadors on horseback or in battle-tell that story in iconographic form. In this respect, while obviously concerned with the representation of space, as Brotton avers and as this image evinces, maps are also often about time, 'ask[ing] viewers to observe how ... events unfold one after another' (Brotton 2012: 5).

Likewise, the 'Wayward Wanderers' Map of Oaxaca' ('an enchanting state, with lovely ladies, handsome dishes, and fine old ruins') plots a human geography of rich and varied ethnicity and history (Fig. 4.5). Here, the southern state's diverse indigenous inhabitants (including the Tejuana and the Mixteca) populate a landscape inhabited by fourteen human figures all dressed in traditional clothing (a key to which is also provided, 'for those who wish to go native', as the map's legend puts it). Each of the figures is devoid of facial features and identified only by means of their distinctive 'costumes', one implication of which is that they are seen as 'types', rather than individuals, whose identities are easily assimilable. That nine of the fourteen figures are 'lovely ladies' indicates too how 'gender is bound up with the nation' (Radcliffe 2011: 209). Such a map has precedents in nineteenth-century imagery of Mexicans as types, as in publications such as Trajes Mexicanos by Casimiro Castro and J. Campillo, which was part of a broader nationalist endeavour after Independence to generate images of the land and people to form and disseminate the idea of nation for internal and external consumption. As such, as Magalí Carrera points out, there is an element of bricolage in all maps, which may be understood as 'assemblages, collages, and

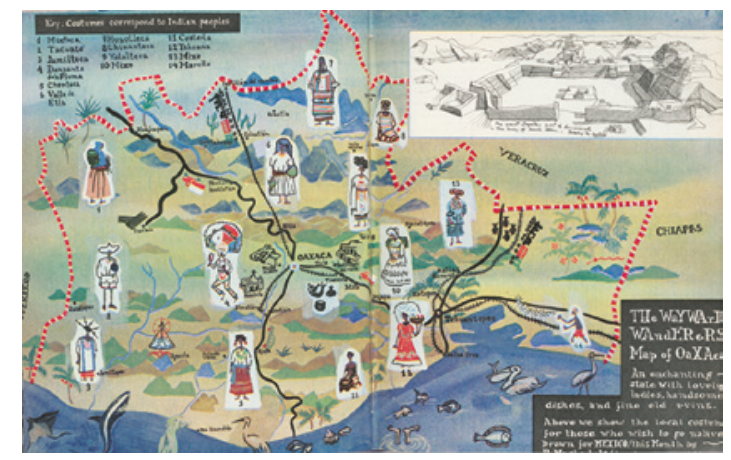

Fig. 4.5 Wayward Wanderers' map of Oaxaca, Mexico This Month, 3:10, 1957 
montages of fragments of earlier maps; debris from previous misrepresentations of spaces and shards of current and past visual images' (2011: 8). The 'Wayward Wanderers' Map of Oaxaca' visually articulates the construction of the map as palimpsest. By way of contrast to the vivid colours of the Indians' clothing, a black and white sketch of Monte Albán in an insert in the map's top right-hand corner provides a ground-level view of those 'fine old ruins': hand-written lettering on the illustration indicates that they are where the 'great Zapotec past is discovered'. Together, the bird's eye view of the state's Indian peoples and the 'close-up' perspectives constitute 'unrealizable views and impossible landscapes in which geographically disparate features [are] collapsed into, and actively ordered within, a single frame' (Craib 2011: 154). While the reader is ostensibly invited to survey Oaxaca 'from an elevated ... Apollonian position', in this map there is in fact little prospect of 'light[ing] out across the territory, for there [is] no "space" in which to wander' (Padrón 2004: 60, 61). In spite of the patent ethnic diversity illustrated therein, the region's physical geography is largely bare and the human geography frozen in space and time. Notwithstanding the pictorial image of a train and the railway lines that bisect the state, the map underscores the region's separatist and anachronistic identity: contained and constrained by a thick, bold, red and white border beyond which the roads and train lines featured on the map do not extend, and the space beyond which is blank, Oaxaca is depicted as a place outside of modernity, outside the nation even. Moreover, its ancient peoples are kept ancient, bound ineluctably to the ruins of a pre-Columbian site: they too are both within and outside the nation/ history. On some level, of course, as much as it illustrates and instructs less-informed readers about the state's and country's differences, such an image is clearly also invested in the longstanding appeal to Mexico's ethnic diversity as a (re)source to be exploited and/or appropriated. In addition to 'the fantasy of capital' sustained in the magazine by the various means described in the previous section, to some degree, the Oaxaca and 'The Trail of Cortez' maps also perpetuate the ongoing fantasy of conquest promised by travel to Mexico. ${ }^{16}$ Indeed, they speak precisely to the ways in which 'maps validate the existence of economic productivity [and colonial extraction] by illustrating it' (Harper 2016: 169).

One of the most vivid representations of the country in these terms and as 'an anachronistic space' (McClintock 1995: 40) is perhaps the 'Complete Explorers' Map for Treasure Hunters on Land and Sea' (Fig. 4.6), which envisages the booty available at various sites across Mexico and its surrounding fishing waters. Here, the fantasy of capital 


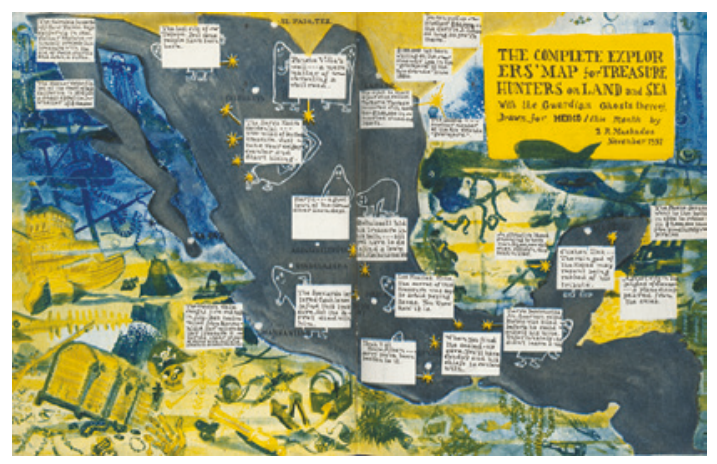

Fig. 4.6 The Complete Explorers' map for Treasure Hunters on Land and Sea, Mexico This Month, 3:11, 1957

and the fantasy of conquest coalesce. As with 'The Trail of Cortés', the 'Treasure Hunters' map depicts a land haunted by its colonial history: the only figures populating the landmass are the 'Guardian ghosts' cheekily peeking out from behind the blocks of explanatory text that appear at different locations, the surrounding blank spaces of the rest of the territory enunciating what Simon Ryan calls 'a statement of economic and demographic availability' (Ryan 1994: 126-127). Indeed, that in this aqueous image the country seems to be almost entirely submerged (nestled in the yellowing sea bed) would seem to reinforce at least one of the terms of that persistent myth of Mexico as a 'dark-skinned Atlantis' (Tenorio Trillo 2010: 20). The explanatory text of the map's narrative labels, however, is marked by a fundamental belatedness, a 'post-touristic irony' evident in other parts of the magazine at different junctures: one label indicates the lost city of Tapoya ('But some people have been here'); another at Los Frailes Mine documents 'the secret of this treasure was kept to avoid paying taxes. You know how it is'; while yet another, at one of Mexico's most visited pre-Columbian archeological sites, reads 'Tomb 7 at Monte Albán - sorry you've been beaten to it'. In this regard, rather than constitute what Michel de Certeau balefully calls 'procedures for forgetting' (1984: 97), the maps of Mexico This Month-while insisting, to be sure, on Mexico's continuing potential as a colonial frontier-also underscore the centrality of history and memory to the journey experience there. In this respect, they function in similar terms to the maps that Owen Dwyer, drawing elsewhere on the work of Pierre Nora, calls memorial texts, 'in which the basis for a particular interpretation is 
endlessly deferred to other texts' with the result being 'the mutual constitution of text and context' (Dwyer 2003: 33). In logging the original and subsequent forms of conquest and exploitation in this manner, the Explorers' Maps interpellate the 'post-tourist' who 'knows that tourism is a series of games with multiple texts and no single, authentic experience' (Urry 2002: 91). In doing so, they also point to a playful revival of the 'pre-modern' function of the map as history book. To some extent this gesture might be seen as part of a larger shift in map production in the late twentieth century mentioned earlier, one which anticipates the emergence of more resistant kinds of cartography (in the form of anti-capitalist maps, for example) from the 1960s onwards. In any case, the Explorers' Maps articulate a complex epistemology regarding the very travel experience and industry in which Mexico This Month was invested and which it promoted. In a manner akin to germane Situationist projects, the series invokes but at the same time wrests mapping from 'the colonizing agency of survey and control' to destabilize its own authoritarian and territorializing origins. As such, it crystallizes that central paradox identified by Craib in his excellent study of cartography in Mexico. That is, the maps of Mexico This Month visualize a tension between the desired fixation of space (in the very drawing up of the map) and what Craib calls the 'fugitive' quality of the landscape, 'places created and recreated through the prism of memory $[\ldots]$ rather than through the lens of instrumentation' (Craib 2004: 12). ${ }^{17}$

Maps, as Jeremy Black claims and as we have seen from the examples discussed here, are similar to caricatures. The Explorers' Maps of Mexico This Month rest on the distortion and exaggeration that animate caricature, but they do so in ambivalent ways. A playful effect is clearly one outcome, although the series' post-touristic irony could be, and was in other instances in the magazine, misinterpreted. An article on archaeology in a later issue of Mexico This Month, like the 'Treasure Hunters' map discussed above, also featured amusing tips for readers on how to locate and access buried treasures, for, it claimed, 'almost any place in the Republic can be picked out as an ideal base for a prober of the past'. The article prompted a complaint to Brenner from the then director of the Museo Nacional de Antropología, Ignacio Bernal, who observed that 'our laws do not allow excavation unless undertaken by a professional archaeologist affiliated with a responsible institution. Anyone taking seriously the [article's] suggestions may end up in jail' (Brenner 1965). Contrary to what Bernal might have thought, in many ways Mexico This Month was, like much of the print media of its day, frequently oficialista 
in character, with plenty of material in its issues to support John Mraz's characterization of Mexico's contemporary illustrated magazines as eminently presidentialist in tone and outlook (2009: 173). The magazine ran regular features on the major achievements of each respective sexenio and in its early issues included a section called 'Quote worth remembering', which often came directly from the president's mouth. Given the circumstances of the magazine's launch, its 'diplomatic' objectives and generous state funding arrangements (to which I return in the next section), this perhaps comes as no surprise. Of more interest is another outcome of the cartographic affinity with caricature discussed here, which articulates a complex position with regard to the industry in which Mexico This Month was invested. The serialization of the Explorers' Maps hints at the impossibility and interminability of the very practice of mapping and the realization that 'the land never remains static for long, whatever the scientific claims to measure and map it accurately' (Brotton 2012: 334). Moreover, and consonant with Brotton's proposal of a 'cartography without progress', as invoked in this chapter's epigraph (words which are true of the fate of many a magazine), the Explorers' Maps of Mexico This Month attest to an aesthetic fusion of touristic and colonial images that might in fact serve oppositional purposes.

\section{III}

If certain maps in the Explorers' Maps series legitimized economic activity by thematizing it, albeit uneasily, Brenner's tribulations as editor of Mexico This Month over the seventeen years of its lifetime also rested largely and often urgently on the issue of capital. Mexico This Month had a complex funding structure: a small percentage of individual subscribers as well as contracts for subscriptions with private companies for the promotion of their services connected with Mexico, as for example, in the case of Humble Oil, who distributed the magazine at its travel information offices on the Mexican border. The magazine's financial security was underwritten, however, by a substantial state subsidy that ensured that the majority of its income derived from bulk 'controlled circulation'. Brenner was mindful of the implications of this for editorial independence, insisting in the magazine's pages and in various memoranda that: 'no publicamos unas gacetillas de ninguna especie, ni políticas ni comerciales ... hemos optado por no comprometer jamás este precioso capital moral que se logra ... siguiendo esta política editorial' [we don't publish sponsored advertising of any political or commercial kind ... we have 
chosen never to compromise that precious moral capital gained by pursuing this editorial policy] (Brenner 1964). Notwithstanding, as mentioned above, the magazine was largely oficialista in tone, both for good and ill. While progressive on the question of Cuba, like many of her mainstream media counterparts, the magazine was largely acquiescent on other political issues of national significance, its tone suitably triumphalist during the 1968 Olympics, for example, though its pages fell silent on the Tlatelolco massacre. Nevertheless, a striking advertisement in the magazine's November 1968 issue, which was still devoted in large part to coverage of the Olympics and its legacy, seems significant in retrospect: an eye-catching announcement of an exhibition of the work of the Catalan artist and regular magazine contributor Bartoli called 'Extermination Camp' at the Juan Martin Gallery: '[his] drawings put down a lifetime of experience with the more violent political phenomena of our time' (14:9, $1968,30)$. As we saw in the previous chapter, here the heterogeneous admixture of different types of (visual, textual, commercial, and editorial) material in the magazine not only 'competes for readers' attention' but can 'work together to create meaning' (Hammill and Smith 2015: 4).

Mexico This Month's subsidy, split between the Banco Nacional de Mexico and Nacional Financiera, and which speaks to the broader dependency of culture on the Mexican state, had aesthetic as well as material implications. The Banco de Mexico was the first to subsidize the magazine, buying 12,000 of its average 30,000 monthly copies on behalf of the Department of Tourism. These were then distributed to embassies, consulates, and tourist delegations in the US and beyond as well as to private enterprises in the tourism sector (Brenner boasted of subscriptions from 'remote' places 'such as India and the Isle of Wight', 2:4, 1956, 7). This was consonant with long-standing endeavours by the central bank, 'one of the most orthodox institutions of Mexican government', in the development of tourism in Mexico. ${ }^{18}$ Nacional Financiera purchased a further 15,000 copies for general promotional purposes which were sent to press, libraries, airlines, travel agencies and universities. ${ }^{19}$ The two subsidies covered the estimated $\$ 2$ unit cost at the magazine's launch in 1955, with a further $30 \%$ discount-agreed by Loyo - on the purchase of paper from a US manufacturer then based in Mexico. Scarcely three years into operations, however, that discount was withdrawn, although increased commercial advertising revenues temporarily compensated for the loss. Brenner acknowledged that the magazine needed to be self-sufficient but lamented that advertising 'es difícil, ya que por lo general [en México] la publicidad en revistas se considera algo así como una propina, en vez de 
un justo pago por valores recibidos' [is difficult, since generally in Mexico magazine advertising is considered like a tip, rather than a fair payment for values received] (Brenner 1964). Notwithstanding, she saw its merit as an indicator of the magazine's independence, its commercial associations aligning it with the 'intereses reales económicos de la nación' [real economic interests of the nation] (Brenner 1964). In 1960 Brenner succeeded in renegotiating with Nacional Financiera to cover the (actual) cost price of $\$ 2.40$ but not with the Banco de Mexico, which regarded the magazine a 'negocio particular' [private business]. From then on, notwithstanding a smaller package deal with Humble Oil and its regular individual subscribers, and with rising costs in printing and paper, the magazine was soon in severe financial straits.

Various measures were proposed and taken to tackle this deficit, including reducing staff and operating costs in addition to cutting issue length and the magazine's frequency. By 1962 Mexico This Month had halved its issue length from an average of thirty-two pages to sixteen. Brenner was then encouraged to buy paper, 'the single biggest expense in manufacturing a periodical' (Rubenstein 2010: 601), from PIPSA. Mexico did not produce much paper of her own and relied on imports largely from Canada and the United States, where the major suppliers were located, and like other commodities, paper's costs varied in response to the strength of the peso and other variables, including the Second World War, which made it scarce and expensive. The stateowned semi-official Productora e Importadora de Papel, S.A. (PIPSA) imported newsprint to Mexico duty free and supplied publishers with paper at cut-rate prices: in providing paper at a steady, low price, it made possible the operation or suspension of mainstream and marginal publications and became a powerful state tool to ensure the political compliance of the print media. In consequence, for most of the twentieth-century PRI hegemony, in a context in which the press historically has had 'complacent relations with state and market interests', the media were 'fully integrated into the structure of power' (Hallin 2000: 83). ${ }^{20}$ Indeed, by the 1940s, PIPSA had so abused its powers that the owners of the largest newspapers in the capital 'were looking for a way around this situation' (Nilbo 1991: 351) and yet, as Rubenstein discloses, between 1940 and 1976, newspapers that were 'independent' of PIPSA 'never lasted more than a year' (Rubenstein 2010: 602). Brenner decried the PIPSA proposal and the paper's poor quality but relented, insisting that it be a 'medida transitoria' [temporary measure] to be used only in certain sections of the magazine. The results she said, writing in 1962, 
were wholly detrimental to the magazine's and thus too to Mexico's image abroad: 'nos mutila el aspecto y causa una malísma impresión en el extranjero' [it maims our appearance and causes a terrible impression abroad] (Brenner 1962). The aesthetic diminishment imposed by the change in paper was thus inimical to the principles of the magazine's foundation, as well as further destabilized its avowed editorial independence. Needless to say, Brenner's enthusiasm for using colour photography, to take advantage of 'Mexico's wealth of beauty in full colour', was also curtailed. 'Most countries', she observed pointedly, 'consider [colour photography] a necessity. However, since it will require about ten times our production costs even to begin to attempt it we can only aim at it as a valuable and necessary thing to do in the future' (Brenner 1960). The magazine's financial arrangements not only found expression in its modified appearance but also circumscribed plans for the expansion of its circulation and diversification. ${ }^{21}$ Brenner's repeated efforts (from the late 1950s onwards) to find a suitable buyer for the magazine and to form an empresa mixta, with Mexican finance and US publishing expertise, came to nothing. ${ }^{22}$ The withdrawal of the government subsidies, first from the Banco de Mexico in 1965, and, then, in December 1970 by Nacional Financiera, ultimately sealed Mexico This Month's fate. The timing of the central bank's withdrawal seems particularly ironic, as it was precisely at that time that it wrote a plan calling for the aggressive marketing of Mexico to potential foreign tourists as an answer to the country's trade and development needs (Clancy 2001: 31).

In different ways, the fortunes of Mexico This Month and the visual language of its Explorers' Maps series both speak to a central ambivalence in the magazine's engagement with tourism over its seventeen-year lifetime. Indeed, the magazine's relationship with capital illuminates one of the many contradictions that emerge from a consideration of tourism in this context. Among these are the tensions relating to efforts to advertise the country's development and modernity through its diversity and history and to promote it as a vacation site to be consumed by US visitors seeking respite precisely from the very modernizing processes then being embraced in Mexico. The fundamental ambivalence, however, which underpinned the 'uneven and non-systematic' approach of the Mexican state to tourism across the post-war/Cold War period was about how to reconcile a desire for national sovereignty with market and geopolitical demands. Accordingly, the endorsement of President Ruiz Cortínez at the launch of Mexico This Month was eclipsed early on and most definitively by the central bank's retreat after the election of the more repressive 
President Díaz Ordaz, who, like President López Mateos before him (1958-1964), wavered in his enthusiasm for tourism. ${ }^{23}$ In essence, for all its efforts to promote development, modernity and the transnational flow of capital, Mexico This Month, though hampered by a certain degree of editorial and official protectionism, was hamstrung by domestic politics and the effects on its finance and production of a state-driven tourist industry which, still in its relative infancy, operated in fits and starts over the two decades of the magazine's operation. One terminal manifestation of this emerged in the late 1960s, when developers and investors started to consider the potential of the Yucatán coastline as a setting for a new beach resort. As Mayas flocked to the area seeking jobs, the 'tourist mecca' of Cancún started to take shape as the first hotels began to open to mostly North American tourists (Sherman 2010: 567). Such attempts to revive the Mexican 'miracle' in the 'Riviera Maya' - together with the development of maquiladoras in the country's border regions-began to stall even by the early 1970s, however, as the contradictions on which Mexico's postwar economic boom rested struggled to keep hold.

In this respect, as Clancy has observed, state reliance on tourism requires constant planning and promotional efforts: at national level this demands perennial newness. Brenner was cognizant of this. An episode documented in her correspondence, which speaks to that demand, provides a fitting yet chilling ending for this chapter's considerations, returning us to that central affiliation between revolution and tourism with which this book began. Revolution and tourism, as I suggested in Chapter 1, are each a source of the 'new'-experientially and conceptually-and this anecdote from Brenner's archive testifies to the deep tensions produced by their coupling. Brenner was committed to both: counting herself among 'las filas intelectuales de la Revolución' [the intellectual ranks of the Revolution], she was throughout her career a tireless advocate of tourism as a form of goodwill ambassadorship. Nevertheless, as Mexico This Month folded in 1971, it was clear to her that in Mexico revolution was no longer synonymous with the modern and that this was a threat to tourism. On 9 June 1971, she wrote to a newly elected President Luis Echeverría attributing the resurgence of an 'inquietante bajón del turismo' [disturbing sharp fall in tourism] to the bloody events in the second half of the Díaz Ordaz sexenio (the massacre of student demonstrators in the Plaza del Tlatelolco) with which Echeverría, as former Minister of Government whose remit included domestic security, was closely associated: 
La imagen de México como país revolucionario ya no existe [en la prensa de allá]. Ha sido destruida por todo lo reporteado de Tlatelolco ... del país del heroico Zapata y el valiente Cárdenas nos hemos transformado al país de los sacrificios humanos.

[The image of Mexico as a revolutionary country no longer exists (in the press over there). It has been destroyed by all the reporting about Tlatelolco ... from the home of heroic Zapata and brave Cárdenas we've become the country of human sacrifice].

The delivery of Brenner's letter was delayed as a result of another homicide that 'had been carried out with orders from the top' (Sherman 2010: 564); what became known as the Corpus Christi massacre, which took place in Mexico City on 10 June $1971 .{ }^{24}$ En route to deliver it, the courier had to take cover for safety during the violence, during which dozens of students were killed. In a second letter to the president's office on 11 June to account for the first's delay, Brenner was apparently unmoved by the demonstrators' plight. Rather, in a gesture which resounds implacably with the founding objectives of the magazine she edited for so long, if not with her own radical past, Brenner's paramount concern was that 'en el extranjero el resultado neto va a ser una impresión de confusión y peligro y va a hacer mucho daño para la entrada del turismo de verano' [abroad the net result will be an impression of confusion and danger and it will do a lot of damage to the start of the summer tourism season] (Brenner 1971).

\section{Notes}

1. In this respect, the following assertion by Carl Thomson (2011: 25) is suggestive: that insofar as they are artfully constructed representations of the world that are often ideologically charged and laden with larger cultural meanings ...one might plausibly include maps ... as a form of travel writing.'

2. Saragoza (2001: 104) claims that 'the mix of Acapulco's significance and Alemán's influence forced reconciliation of the "modern" tourism exemplified by beachside resorts with the heritage-based approach of the 1930s'.

3. For more on this see Anderson (1998).

4. Brenner insisted that the members of the magazine's founding committee, many of them business men, had such intimacy with the country, garnered through years of residency there, that they 'have developed a feeling almost as if its problems were like illness in the family, and its accomplishments, personal triumphs' (Mexico This Month, 1:1, 6). 
5. See Mexico This Month, 1:2 (1955). For more on this see Cohn (2005).

6. See, respectively, Mexico This Month, 2:8 (August 1956); 9:5 (August 1963); 2:12 (December 1956).

7. Brenner's experiment with launching a mail order rebozo business was eventually hamstrung by irregularities in the postal service, an experience she equated with 'the Sorcerer's Apprentice carrying his buckets of water' $(5: 12,1959,7)$.

8. Patricia Okker claims that a rhetoric of intimacy-or 'sisterly editorial voice' - was a trademark of periodicals edited by and for women in the US in the nineteenth century. See Okker (1995: 23).

9. In the Anglophone world, for example, it was during this period that the Ordnance Survey of Great Britain started to make tourist maps for the leisure market, 'with evocative illustrated covers and in a convenient folded format'. Harper (2016: 149).

10. For more on branding in Latin America see Fehimović and Ogden (2018).

11. For more on how US advertisers tapped into Mexican nationalism during and after WWII, see Moreno (2003).

12. For a fascinating discussion of maps and money see also Brotton (2012: 260-293). On the use of the figure of the cornucopia as a trope in Mexico's visual culture, see Carrera (2011: 117).

13. The Casa de la Contratación used information from voyages to the Americas to modify and update maritime charts and also produced the padrón general, 'a master chart of the known world'. For more on this see Carrera (2011: 39).

14. Indeed, as the Paseo began to develop during the Porfiriato the city began to divide in two: the wealthy, including the American colony, in the west, while 'the eastern part of the city remained a place for the poor'. Boardman (2001: 48).

15. Garrigan shows how the history behind these statues reveals the critical tensions between patrimony and commerce, the very conditions the former was supposed to transcend. She illustrates, for example, how the statue to Columbus was, rather than 'inspired nationalism', in fact 'a compensatory gesture for a failed business transaction in which [Antonio] Escandón [the Mexican capitalist who had commissioned the monument] had been unable to fulfill his original obligation' (Garrigan 2012: 107, 118).

16. I have borrowed this useful phrase from James Martin (2011).

17. Brotton, in relation to the Carte de Cassini, 'the first modern map of a nation', concurs that 'any national survey [is] potentially endless' (2012: 334).

18. For example, when the National Trust for Tourist Infrastructure (INFRATUR) was created in 1969 it was administered within the central 
bank, 'indicat[ing] that tourism promotion came in response to balance of payments pressures and was conceived of mainly as an export project' (Clancy 2001: 51).

19. Nacional Financiera was 'a credit institution which aided investment [in Mexico] by floating bonds and managing both public and private funds, including many of the major loans granted for public works' (Sherman 2010: 547).

20. PIPSA had the authority to provide its clients, both newspapers and journals, not only with their own supply but, indeed, with a surplus of paper which could then be sold at a profit to buyers without the requisite governmental approval, an unofficial income that 'in some cases accounted for up to $40 \%$ of a newspaper's income'. See Cohn (2005: 174).

21. These included a convention service and a multi-media package for schools, as well as other teaching materials for Chicano programmes in the US.

22. Brenner attempted to convene an 'empresa mixta' with capital investment from Mexico, and editorial and production talent from the US. In 1971, she also investigated the possibility of the Holiday Inn using Mexico This Month in its promotional material specifically in the Holiday Inn magazine.

23. Both presidents were hesitant to promote tourism more strongly, says Clancy, which resulted from problems with border tourism. Coastal tourism, as a result, was neglected at this time. But the withdrawal of the central bank might also have to do with the state's retreat from a more aggressive stance as entrepreneur and banker to more of a back seat as private investment began to increase during this period.

24. At a student demonstration, a crowd of right-wing thugs set upon unarmed protesters with knives and light weapons, killing two or three dozen of them, as police stood and watched.

\section{REFERENCES}

Anderson, Mark C. 1998. 'What's to Be Done with 'Em?' Images of Mexican Cultural Backwardness, Racial Limitations, and Moral Decrepitude in the United States Press 1913-1915.' Mexican Studies/Estudios Mexicanos 14 (1): 23-70.

Boardman, Andrea. 2001. Destination Mexico, 'A Foreign Land a Step Away': US Tourism to Mexico 1880s-1950s. Dallas: Southern Methodist University.

Brenner, Anita.1932. Your Mexican Holiday. New York: Putnams.

- 1955. 'Closing Speech to the Congress of Inter-American Studies.'

University of Florida, December, Anita Brenner Papers 16:8.

— 1959. Anon. to Anita Brenner, 12 June, n.p. Anita Brenner Papers 83:9. 
1960. Memorandum on Tourist Travel. Anita Brenner Papers 108:5.

- 1962. Memorandum. 24 de abril. Anita Brenner Papers 108:5.

- 1964. Memo on Tourist Travel. Anita Brenner Papers 108:5.

- 1965. Ignacio Bernal to Anita Brenner, 9 September. Anita Brenner Papers 83:1.

- 1967. Anita Brenner to Xerox, 25 October. Anita Brenner Papers 97:3.

- 1971. Anita Brenner to Fausto Zapata Loredo, Subsecretaria de la Presidencia, 11 June. Anita Brenner Papers 96:4.

- n.d. Memorandum, Anita Brenner Papers 96:5.

Brotton, Jerry. 2012. A History of the World in Twelve Maps. London: Penguin.

Carrera, Magalí. 2011. Travelling from New Spain to Mexico: Mapping Practices of 19th-Century Mexico. Durham: Duke University Press.

Clancy, Michael. 2001. Exporting Paradise: Tourism and Development in Mexico Amsterdam: Pergamon.

Cohn, Deborah. 2005. 'The Mexican Intelligentsia, 1950-1968: Cosmopolitanism, National Identity, and the State'. Mexican Studies/Estudios Mexicanos 21 (1): 141-182.

Corner, James. 1999. 'The Agency of Mapping: Speculation, Critique and Invention.' In Mappings, edited by Denis Cosgrove, 213-252. London: Reaktion.

Cosgrove, Denis. 1999. 'Introduction: Mapping Meaning.' In Mappings, edited by Denis Cosgrove, 1-23. London: Reaktion.

Craib, Raymond. 2004. Cartographic Mexico: A History of State Fixations and Fugitive Landscapes. Durham: Duke University Press.

—. 2011. 'Historical Geographies.' In Mapping Latin America: A Cartographic Reader, edited by Jordana Dym and Karl Offen, 153-158. Chicago: University of Chicago Press.

de Certeau, Michel. 1984. The Practice of Everyday Life. Berkeley: University of California Press.

Dwyer, Owen J. 2003. 'Memory on the Margins: Alabama's Civil Rights Journey as a Memorial Text.' In Mapping Tourism, edited by Stephen P. Hanna and Vincent J. del Casino Jr., 28-50. Minneapolis: University of Minnesota Press.

Fehimović, Dunja, and Rebecca Ogden, eds. 2018. Branding Latin America: Strategies, Aims, Resistance. Lanham: Lexington Books.

Garrigan, Shelley E. 2012. Collecting Mexico: Museums, Monuments, and the Creation of National Identity. Minneapolis: University of Minnesota Press.

Gillingham, Paul, and Benjamin T. Smith, eds. 2014. Dictablanda: Politics, Work, and Culture in Mexico, 1938-1968. Durham: Duke University Press.

Glusker, Susannah Joel. 1998. Anita Brenner: A Mind of Her Own. Austin: University of Texas Press.

Hallin, Daniel C. 2000. 'Media, Political Powers and Democratization in Mexico.' In De-Westernising Media Studies, edited by J. Curran and M.-J. Park, 85-97. London and New York: Routledge. 
Hammill, Faye, and Michelle Smith. 2015. Magazines, Travel and Middlebrow Culture: Canadian Periodicals in English and French 1925-1960. Liverpool: Liverpool University Press.

Hammill, Faye, Paul Hjartarson, and Hannah McGregor. 2015. 'Introducing Magazines and/as Media: The Aesthetics and Politics of Serial Form.' ESC: English Studies in Canada 41 (1): 1-18.

Hanna, Stephen P., and Vincent J. del Casino Jr., eds. 2003. Mapping Tourism. Minneapolis: University of Minnesota Press.

Harley, J. B., and David Woodward. 1992. History of Cartography. Vol. I. Chicago: University of Chicago Press.

Harmon, Katharine. 2009. The Map as Art: Contemporary Artists Explore Cartography. New York: Princeton Architectural Press.

Harper, Tom. 2016. Maps and the Twentieth Century. London: British Library.

Johns, Michael. 1997. The City of Mexico in the Age of Diaz. Austin: University of Texas Press.

Martin, James. 2011. 'Mapping an Empire: Tourist Cartographies of the Caribbean in the Early 20th Century.' Early Popular Visual Culture 9 (1): 1-14.

McClintock, Anne. 1995. Imperial Leather: Race, Gender and Sexuality in the Colonial Contest. New York: Routledge.

Monsivais, Carlos. 2010. 'Introduction: Anita Brenner: The (Multiple) Story of Origins.' In Avant Garde Art and Artists in Mexico: Anita Brenner's Journals of the Roaring Twenties and Thirties, edited by Susannah Joel Glusker, xi-xxiv. Austin: University of Texas Press.

Moreno, Julio. 2003. Yankee Don't Go Home! Mexican Nationalism, American Business Culture, and the Shaping of Modern Mexico, 1920-1950. Chapel Hill: University of North Carolina Press.

Mraz, John. 2009. Looking for Mexico: Modern Visual Culture and National Identity. Durham: Duke University Press.

Nilbo, Stephen R. 1991. Mexico in the 1940s: Modernity, Politics, and Corruption. Wilmington: Scholarly Resources.

Okker, Patricia. 1995. Our Sister Editors: Sarah J. Hale and the Tradition of Nineteenth-Century Woman Editors. Athens: University of Georgia Press.

Padrón, Ricardo. 2004. The Spacious Word: Cartography, Literature and Early Modern Spain. Chicago: University of Chicago Press.

Radcliffe, Sarah A. 2011. 'Representing the Nation.' In Mapping Latin America: A Cartographic Reader, edited by Jordana Dym and Karl Offen, 207-210. Chicago: University of Chicago Press.

Rubenstein, Anne. 2010. 'Mass Media and Popular Culture in the Postrevolutionary Era.' In The Oxford History of Mexico, edited by William $\mathrm{H}$. Beezley and Michael C. Meyer, 598-634. New York: Oxford University Press.

Ryan, Simon. 1994. 'Inscribing the Emptiness: Cartography, Exploration and the Construction of Australia.' In De-Scribing Empire: Postcolonialism and Textuality, edited by Chris Tiffin and Alan Lawson, 126-127. London: Routledge. 
Salvatore, Ricardo. 1998. 'The Enterprise of Knowledge: Representational Machines of Informal Empire'. In Close Encounters of Empire: Writing the Cultural History of U.S.-Latin American Relations, edited by Gilbert Joseph, Catherine Le Grand, and Ricardo Salvatore, 69-104. Durham: Duke University Press.

Saragoza, Alex. 2001. 'The Selling of Mexico: Tourism and the State, 19291952.' In Fragments of a Golden Age: The Politics of Culture in Mexico Since 1940, edited by Gilbert Joseph, Anne Rubenstein, and Eric Zolov, 91-115. Durham: Duke University Press.

Sherman, John. 2010. 'The Mexican "Miracle” and its Collapse.' In The Oxford History of Mexico, edited by William Beezly and Michael C. Meyer, 537-568. Oxford: Oxford University Press.

Shields, Rob. 2003. 'Political Tourism: Mapping Memory and the Future of Quebec City.' In Mapping Tourism, edited by Stephen P. Hanna and Vincent J. Del Casino Jr., 1-27. Minneapolis: University of Minnesota Press.

Tenorio Trillo, Mauricio. 2010. 'El peso de una imagen: México.' In México ilustrado: libros, revistas y carteles 1920-1950, edited by Salvador Albiñana, 20. Mexico: Editorial RM.

- 2012. I Speak of the City: Mexico at the Turn of the 20th Century (18801940). Chicago: University of Chicago Press.

Thompson, Carl. 2011. Travel Writing. Oxford and New York: Routledge.

Urry, John. 2002. The Tourist Gaze, 2nd ed. London: Sage.

Woods, Richard D. 1990. 'Anita Brenner: Cultural Mediator for Mexico.' Studies in Latin American Popular Culture 9: 209.

Open Access This chapter is licensed under the terms of the Creative Commons Attribution 4.0 International License (http://creativecommons.org/licenses/ by $/ 4.0 /)$, which permits use, sharing, adaptation, distribution and reproduction in any medium or format, as long as you give appropriate credit to the original author(s) and the source, provide a link to the Creative Commons license and indicate if changes were made.

The images or other third party material in this chapter are included in the chapter's Creative Commons license, unless indicated otherwise in a credit line to the material. If material is not included in the chapter's Creative Commons license and your intended use is not permitted by statutory regulation or exceeds the permitted use, you will need to obtain permission directly from the copyright holder.

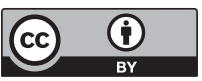

